\title{
PENDIDIKAN PANCASILA DAN KEWARGANEGARAAN \\ UNTUK KELOMPOK MASYARAKAT \\ (CITIZENSHIP EDUCATION FOR SOCIAL COMMUNITY)
}

Oleh: Yuyus Kardiman*

\begin{abstract}
The biggest problems in the Pancasila and Civic Education in fact not on how the Pancasila and Civic Education implemented a formal educational institution, but Pancasila and Civic Education conducted by the non-formal institutions both family and society. More social problems that occur due to the inability of society to educate both by example and efforts to socialize knowledge and values. For this reason the development efforts of Pancasila and Civic Education for the community to be important, especially in Indonesia.
\end{abstract}

Key Words: Pancasila and civic education, society.

\section{A. Pendahuluan}

1. Latar Belakang

Pendidikan selalu menjadi sorotan dalam upaya pembangunan setiap bangsa, begitupun di Indonesia, pendidikan selalu menjadi trend topic yang selalu dipermasalahkan. Berbagai persoalan mengenai pendidikan terus mengemuka, mulai dari persoalan Ujian Nasional, Pendidikan karakter yang luntur, guru yang tidak berkualitas, sehingga pergantian kurikulum dalam mengatasi berbagai masalah tersebut, yang akhirnya kurikulumnya dianggap bermasalah juga.

Persoalan di atas menggambarkan bahwa belum stabilnya system pendidikan kita, sehingga secara langsung ataupun tidak berpengaruh terhadap kualitas pendidikan itu sendiri. Terlebih adanya pemahaman yang keliru, yaitu ketika mendengar pendidikan apalagi konsep Pendidikan Kewarganegaraan (civic Education), kadang kita terjebak pada pemikiran bahwa pendidikan itu adalah sekolah yaitu suatu lembaga formal yang dimiliki oleh Negara atau swasta yan dilakukan dalam sebuah gedung sekolah dan berbagai fasilitas yang ada di dalamnya, kurikulum dan guru serta komponen sekolah lainnya yang ada.

Sehingga ketika adanya persoalan sosial (konflik sosial) dalam masyarakat, seperti tawuran antar pelajar/mahasiswa, yang akhirnya merembet menjadi tawuran antar kelompok masyarakat, suku bahwak mengatanamanakan agama, tingkat kriminalitas yang semakin tinggi yang tidak jarang dilakukan oleh anak usia sekolah, kasus asusila, obat-obat terlarang, vandalism, dan sebagainya, tidak jarang masyarakat menjadikan lembaga pendidikan

*Dosen Program Studi Pendidikan Pancasila dan Kewarganegaraan Jurusan Ilmu Sosial Politik, Fakultas Ilmu Sosial Universitas Negeri Jakarta 
formal (sekolah) itulah yang menjadi penyebab utama. Bahwa Sekolah tidak berhasil melakusanakan pendidikan moral atau karakter, sekolah tidak memberikan keterampilan yang jelas bagi siswanya, sekolah membebankan orang tua, dan sebagainya.

Terlebih, Pendidikan Kewarganegaraan yang sangat sarat dengan pendidikan nilai dan moral, pendidikan demokrasi, pendidikan hukum, pendidikan hak asasi manusia, nasionalisme, pendidikan multicultural, seolah memiliki beban yang berat dalam menghadapi segala persoalan tersebut di atas. Sehingga tidak sedikit yang mempersalahkan guru Pendidikan Kewarganegaraan ketika terjadi permasalah tersebut.

Dari permasalahan di atas, maka perlu kiranya ada penjelasan rasional serta upaya untuk memecahkan berbagai persoalan yang menjadi salah satu tanggung jawab dari Pendidikan Kewarganegaraan untuk kehidupan masyarakat Indonesia yang lebih baik.

Berbicara pendidikan sangatlah luas, pendidikan milik semua pihak, baik pihak sekolah, orang tua, masyarakat, dan Negara. Menurut UU No. 20 tahun 2003 Bab VI Pasal 13 Ayat 1 jalur pendidikan terdiri atas pendidikan formal, nonformal, dan informal yang dapat saling melengkapi dan memperkaya. Pendidikan formal adalah jalur pendidikan yang terstruktur dan berjenjang yang terdiri atas pendidikan dasar, pendidikan menengah, dan pendidikan tinggi. Pendidikan nonformal adalah jalur pendidikan di luar pendidikan formal yang dapat dilaksanakan secara terstruktur dan berjenjang. Pendidikan informal adalah jalur pendidikan keluarga dan lingkungan.

Begitupun dengan Pendidikan Kewarganegaraan, tidak saja ada dalam pembelajaran di persekolahan saja, melainkan juga bergerak pada kehidupan masyarakat. Hal ini dikemukakan Cogan (1998:1) yang menyatakan "What is called for is a new conception of citizenship education, one in which both schools and the communities they serve and are a part of, are equal partners in the education of each new generation of citizens." Hal ini menjelaskan bahwa dalam konsepsi baru tentang pendidikan kewarganegaraan, salah satunya adalah dimana antara sekolah dan masyarakat merupakan mitra yang sejajar untuk melayani dan melakukan pendidikan bagi generasi baru sebagai warga Negara.

Hal inilah yang menjadi persoalan bangsa ini sekarang, bahwa pada tataran masyarakat belum terbangun pendidikan kewarganegaraan yang optimal, sehingga pendidikan kewarganegaraan disekolah seolah tidak mendapatkan dukungan dari pihak masyarakat (sektor pendidikan informal). 
Untuk itulah penulis tertarik untuk menulis ide-ide dalam bentuk artikel ini dengan judul "Pendidikan Kewarganegaraan bagi Masyarakat" (Civic Education for Civic Community)

\section{Rumusan Masalah}

Dari latar belakang di atas maka penulis membuat rumusan masalah sebagai berikut:

1) Permasalahan apa saja yang muncul dalam pendidikan kewarganegaraan pada masyarakat dewasa ini?

2) Bagaimana upaya membangun Pendidikan Kewarganegaraan bagi masyarakat untuk menciptakan masyarakat yang demokratis?

\section{Tujuan Penulisan}

Tujuan dari penulisan artikel ini adalah sebagai berikut:

1) Untuk mengentahui permasalahan apa saja yang terjadi dalam upaya pendidikan kewarganegaraan pada masyarakat dewasa ini.

2) Untuk mengembangkan pendidikan kewarganegaraan (baik kelembagaan maupun konten) dalam masyarakat, sehingga terciptanya masyarakat yang demokratis.

\section{Pembahasan}

a. Urgensi Pendidikan Kewarganegaraan bagi Masyarakat

Demokrasi tidak didapatkan melalui keturunan atau kelahiran, melainkan merupakan suatu proses panjang melalui pendidikan dan pembudayaan, seperti dikemukakan oleh Winataputra (2006) bahwa "democracy isn't inherrited, but it is learned", hal ini menjelaskan akan pentingnya pendidikan demokrasi pada suatu masyarakat. Tidak saja masyarakat sekolah, melainkan juga kelompok masyarakat informal yakni lingkungan sekolah termasuk orang tua di dalamnya.

Seperti yang dikemukakan oleh Cogan pada bagian latar belakang di atas, bahwa Pendidikan kewarganegaraan tidak saja ada pada domain sekolah, melainkan ada juga pada domain masyarakat (kultural) dimana PKn dalam masyarakat memiliki konten, tugas dan fungsi sejajar dengan demain sekolah, hal ini sesuai dengan pendapat Sapriya (2007:281-282) yang menyatakan bahwa domain PKn sebagai program sosial kultural pada hakikatnya tidak banyak perbedaan dengan program kurikuler dilihat dari aspek tujuan, pengorganisasian kurikulum, dan materi pembelajaran. Perbedaannya terutama pada aspek sasaran, kondisi, dan karakteristik peserta didik. Program PKn ini dikembangkan dalam konteks kehidupan masyarakat dengan sasaran 
semua anggota masyarakat. Tujuannya lebih pada upaya pembinaan warga masyarakat agar menjadi warga Negara yang baik dalam berbagai situasi dan perkembangan zaman yang senantiasa berubah.

Hal ini di dasari juga oleh pemikiran Winataputra (2001, 2006) tentang Pendidikan Kewarganegaraan memiliki visi akademis dan pedagogis, yang meliputi tiga domain, yaitu, 1) domain kurikuler, yaitu domain pendidikan kewarganegaraan yang dikembangkan dipersekolahan, 2) domain kajian ilmiah, yaitu pendidikan kewarganegaraan yang dikembangkan di perguruan tinggi, serta 3) domain social kultural, yaitu pendidikan kewarganegaraan yang dikembangkan pada masyarakat.

Peter Levine ( 2012:55) menjelaskan bahwa "civic education should help to strengthen and sustain a civil society in which young people participate as citizens and learn the skills, knowledge, and values they need in the broader public sphere dominated by adults."

Pendidikan kewarganegaraan akan membantu untuk memperkuat dan mempertahankan suatu masyarakat sipil (civil society) di mana warga negara muda berpartisipasi sebagai warga negara untuk belajar keketerampilan, pengetahuan, dan nilai-nilai yang mereka butuhkan dalam lingkup masyarakat yang lebih luas dari dominasi warga negara dewasa.

Hal di atas menunjukkan dua hal yang penting dalam pendidikan kewarganegaraan . Pertama, pendidikan kewarganegaraan di persekolahan yang harus terus di kembangkan, sehingga mampu mempersiapkan warga negara muda untuk berpartisipasi dalam kehidupan demokratis dalam masyarakat. Kedua,pengembangan pendidikan kewarganegaraan pada masyarakat civil melalui civic community.

Arti penting pendidikan kewarganegaraan ini, berkaitan tujuan dari PKn itu sendiri. Hal ini dapat kita lihat dari konten PKn secara ontology. Konten dalam PKn meliputi tiga dimensi yaitu dimensi pengetahuan kewarganegaraan (civic knowledge), dimensi keterampilan kewarganegaraan (civic skill), dan dimensi nilai kewarganegaraan (civic value), dengan penjelasan sebagai berikut:

1) Dimensi pengetahuan kewarganegaraan (civic knowledge), yang menyangkut bidang politik, hukum dan normal, sehingga membawa konsekueni materi kuliah PKn meliputi pengetahuan tentang prinsip dan demokrasi, lembaga pemerintahan dan non pemerintahan, identitas nasional, rule of law, peradilan yang bebas dan objektif, sejarah nasional, hak dan 
tanggungjawab warga negara, HAM dan hak politik.

2) Dimensi ketrampilan kewarganegaraan (civil skill), yaitu yang menyangkut ketrampilan dalam berpartisipasi di dalam kehidupan berbangsa dan bernegara. Oleh karena itu, peserta didik harus diberikan kesempatan untuk ikut mewujudkan masyarakat madani, ketrampilan memngaruhi, ketrampilan monitorig jalannya pemerintahan, ketrampilan dalam mengambil keputusan, ketrampilan dalam memecahkan masalah sosial, ketrampilan berkoalisi, dan ketrampilan mengelola konflik.

3) Dimensi nilai kewarganegaraan (Civic Value), maksudnya materi prkuiiahan mengarah pada penanaman nilai, ke[ercayaan serta sikap kewarganegaraan yang baik. Materi yang terkait dengan dimensi ini adalah komitmen, penguasaan nilai keagamaan, norma dan etika, nilai keadilan, demokrasi, kebebasan berpedapat, dan perindungan.

Sejalan dengan Branson (dalam Kardiman, 2008:47) yang menyatakan bahwa Pendidikan Kewarganegaraan merupakan pendidikan yang mengandung tiga komponen utama yang cocok untuk dikembangkan pada masyarakat yang demokratis yaitu pengetahuan kewarganegaraan (civic knowledge), kecakapan kewarganegaraan (civic skill), dan watakwatak kewarganegaraan (civic disposition).

Civic Knowledge adalah pengetahuan kewarganegaraan yang berkaitan dengan kandungan atau apa yang seharusnya diketahui oleh warga Negara meliputi politik dan pemerintahan, konstitusi, tujuan, nilai-nilai dan prinsip demokrasi, hubungan Negara dengan Negara lain serta peran warga Negara.

Civic Skill yaitu kemampuan warga Negara untuk mempraktekkan hak-haknya dan menunaikan tanggung jawabnya sebagai anggota masyarakat yang berdaulat berdasarkan pengetahuan kewarganegaraan yang telah dimiliki.

Civic disposition yaitu mengisaratkan kepada karakter masyarakat maupun perseorangan dari warga Negara yang penting bagi pemeliharaan dan pengembangan demokrasi konstitusional. watak-watak kewarganegaraan sebagaimana kecakapan kewarganegaraan, berkembang secara perlahan sebagai akibat dari apa yang telah dipelajari dan dialami oleh seseorang di rumah, sekolah, komunitas, dan organisasi-organisasi civil society.

Ketiga domain, merupakan acuan dalam melakukan transfer of value, transfer knowledge, transfer of skill, transfer of culture dari nilai-nilai 
kebangsaan Indonesia, yakni nilai-nilai Pancasila. Nilai-nilai Pancasila seharusnya menjadi karakter yang dibangun dalam Pendidikan Kewarganegaraan, bahkan dalam pendidikan pada umumnya.

Hal inilah yang pada saat ini mulai dirasakan hilang dalam kehidupan pendidikan nasional kita, tidak saja di dunia persekolahan, terlebih pada lingkungan masyarakat. Masyarakat seolah kehilangan arah, bukan saja tidak memahami apa yang harus dilakukan, tetapi lebih dasar lagi banyak perilaku masyarakat yang tidak tahu mana yang salah dan yang benar. Sudah saatnya bahwa kita melakukan revitalisasi pendidikan kewarganegaraan dengan menghidupkan kembali nilai-nilai Pancasila sebagai landasan kehidupan demokratis Indonesia. Untuk perlu kiranya penulis menguraikan secara singkat arti pentingnya nilai-nilai Pancasila dalam kehidupan bangsa ini.

Nilai Ketuhanan, dalam sila pertama Pancasila "Ketuhanan Yang Maha Esa", dijadikan dasar bagi sila-sila yang lainnya, atau disebut juga dasar dari yang dasar. Karena nilai ini dianggap menjadi nilai dasar bagi kehidupan manusia. Nilai Ketuhanan yang menjelaskan bahwa manusia sesungguhnya adalah sebuah akibat, karena tidak mungkin ada kelahiran tanpa ada yang melahirkan, manusia sebagai makhluk citaan, sehingga pasti ada yang menciptakan. Sehingga Tuhan lah sebagai penyebab akan adanya manusia di dunia. Bangsa Indonesia melalui the founding fathers dengan kajian filsafati ini sepakat bahwa manusia khususnya Indonesia harus menyandarkan segala bentuk kehidupannya kepada Ketuhanan Yang Maha Esa. BerKetuhanan berarti percaya bahwa setiap manusia di dunia ini adalah sama sebagai ciptaan Tuhan, sehingga sesame ciptaan Tuhan sudah selayaknya saling menghormati, menghargai, menyayangi.

Nilai Kemanusiaan, dalam sila kedua Pancasila "Kemanusiaan Yang Adil dan Beradab," dijelaskan bahwa jika manusia sudah memahami bahwa dirinya malhkuk Tuhan, dan harus menyandarkan sgala kehidupannya kepada Tuhan, maka apapun yang diciptakan Tuhannya harus disyukuri, dihargai, dihormati, disayanyi, dicintai. Karena Tuhan pasti sudah merencanakan segalanya untuk kehidpan manusia. (teori sistem). Maka begitupun keberadaan manusia, jika kita lihat bahwa manusia itu berbeda-beda, suku, ras, keyakinan, adat, budaya dan sebagainya, maka hal ini bukan merupakan suatu kebetulan belaka, melainkan suatu kepastian, bahwa Tuhan menciptakan perbedaan. Sehingga hakikinya perbedaan antar umat manusia merupakan suatu anugerah yang perlu manusia rayakan, sehingga dapat menjadi suatu kekuatan 
satu sama lain. Untuk itu sila kedua ini memberikan semangan untuk mansuia Indonesia dapat saling mengembangkan nilai-nilai kemanusiaan, yaitu dapat saling menghargai dan menghormati satiap perbedaan, karena hal itulah yang akan menjadi dasar bagi terciptannya manusia yang adl dan beradab.

Nilai Persatuan, dalam sila ketiga Pancasila "Persatuan Indonesia". Persatuan adalah semangat intrinsic yang di inginkan oleh bangsa Indonesia kepada setiap warga negaranya. Semangat ini dapat tercipta jika pengamalan sila pertama dan kedua dari Pancasila sudah terwujud.

Dan jika nilai sila ketiga sudah terwujud apapun persoalan bangsa ini pasti akan dapat diselesaikan dengan baik, dengan kekuatan filsafat demokrasi yang dianut yaitu "Kerakyatan yang dipimpin oleh hikmat kebijaksanaan dalam permusyawaratan perwakilan”. Empat nilai dari empat sila inilah yang akan menghantarkan bangsa Indonesia mendapatkan "keadilan social bagi seluruh Indonesia".

b. PersoalanPendidikan kewarganegaraan dalam masyarakat di Indonesia

Sebuah pengalaman penulis ketika mengunjungi sebuah lembaga sosial di Singapura namanya "Mendaki", yakni sebuah organisasi non pemerintah (lembaga sosial) bagi orang Melayu, yang bertujuan untuk melakukan pendidikan, perlidungan, dan pemberdayaan bagi setiap warga Negara ras Melayu di negari itu. Ada beberapa program yang menurut penulis menarik dalam kaitannya Pendidikan Kewarganegaraan, yakni, 1) program pendidikan keterampilan buat orang tua, yaitu setiap seminggu sekali diadakan pelatihan atau pendidikan khusus bagi para ibu-ibu dengan materi tidak saja keterampilan dasar seperti memasak, menjahit, dan keterampilan lain yang bersifat materil, jauh dari itu mereka menyelenggarakan pendidikan tentang bagaimana mengelola keluarga bahkan mempersiapkan mereka untuk memberikan pelajaran tambahan diluar sekolah kepada anak-anak mereka. 2) program kakak angkat/asuh, yaitu suatu program yang bertujuan untuk memberikan wadah bagi anak-anak sekolah untuk bisa berbagi (berkomunikasi) dengan sesamanya (diluar orang tua) yang dianggap aman dan melindungi secara fisik maupun psikologis.

Dalam perjalanan sejarah bangsa, Indonesia pernah menyelenggarakan PKn melalui program sosiokultural pada masa pemerintahan orde baru, yakni melalui berbagai program P-4. Program ini sekarang sudah tidak ada lagi karena dipandang telah menyimpang dari tujuan sehingga tidak efektif lagi. Namun dipandang dari sudut kepentingan berbangsa dan bernegara, terutama dalam 
pembangunan karakter bangsa, PKn melalui program social kultural ini sangatlah penting. Oleh karena itu, program PKn dalam dimensi social kultural pada pasca dibubarkannya BP7 dan penghentian program Penataran P4 perlu direvitalisasi sesuai dengan tuntutan dan kebutuhan pembangunan karakter warga Negara Indonesia yang baik.

Beberapa persoalan dasar upaya pendidikan kewarganegaraan bagi masyarakat yang terjadi:

1) Tidak adanya lembaga khusus atau pihak tertentu yang bertanggung jawab akan pendidikan kewarganegaraan pada masyarakat.

Seperti sudah dibahas di atas, bahwa meskipun pendidikan kewarganegaraan ini diselenggarakan bagi masyarakat, tetapi tetap Negara harus bertanggung jawab dalam pelaksanaannya, tidak bisa diberikan secara utuh kepada pihak masyarakat, karena hal ini berkaitan dengan tujuan, konten serta ketercapaian dari tujuan tersebut.

Ketika masa orde baru, program P4 yaitu Program Pedoman, Penghayatan dan Pengalaman Pancasila, yang tanggung jawabnya dilaksanakan oleh sebuah lembaga khusus bernama BP-7, yaitu singkatan dari Badan Pembina Pendidikan Pelaksanaan Pedoman Penghayatan dan Pengamalan Pancasila. Program ini dilaksanakan tidak saja pada lembaga persekolahan dan perguruan tinggi, tetapi seluruh lapisan masyarakat baik pegawai negeri sipil dari golongan I sampai golongan IV, karyawan swasta, masyarakat umum yang terhimpun dalam organisasiorganisasi baik partai maupun nonpartai, bahkan organisasi akar rumput seperti kelompok PKK dan organisasi Karang Taruna, semuanya mendapatkan program ini. Sehingga harus kita akui, bahwa kelebihan upaya pembangunan politik yang dilakukan pada masa Orde Baru adalah dengan program $\mathrm{P} 4$ terciptanya masyarakat yang lebih terarah dalam membangun civil society. Namun sayang karena program ini dilaksanakan pada masa orde baru, seolah melekat sebagai produk orde baru dalam mambangun politik dan mempertahankan kekuasaan orde baru, sehingga program ini di hentikan, bahkan lembaganyapun di bubarkan. Padahal secara konten, program ini memiliki tingkat independesi yang cukup kuat, dan penting ada pada setiap generasi tanpa melihat rezim siapa yang sedang berkuasa, hal ini dikarenakan tujuan dari program ini yang selaras dengan pendidikan kewarganegaraan dalam rangka membangun nilai-nilai demokratis sehingga terciptanya masyarakat madani yang diidam-idamkan (civil society). 
2) Banyak situs kewarganegaraan yaitu lembaga/organisasi/komunitas/tempat warga negara berkumpul bahkan belajar tetapi tidak memahami bahwa itu berkaitan atau dapat dikaitkan dengan upaya pendidikan kewarganegaraan (konten, visi, misi, strategi pembelajaran)

Istilah Situs Kewarganegaraan (site of Citizenship) menurut Educational Democratic of Citizenship/EDC (dalam Winataputra, 2001:219) yaitu suatu label dari studi tentang "educational for democratic citizenship", yang memusatkan perhatian pada "the management of democratic life," atau pengelolaan kehidupan yang demokratis, yang dilakukan pada berbagai arah kehidupan antara lain "...school, communities, workplace, neighborhood, cities, rigiion where the participants give everyday meanings to modrn democratic citizenship." Yang dijelaskan lebih lanjut oleh Winataputra $(2007: 151)$ bahwa situs kewarganegaraan atau site of citizenship merupakan modus lain dari pendidikan kewarganegaraan yang mencakup berbagai kegiatan yang amat bervariasi dalam tujuan dan formatnya. Hal tersebut menunjukkan betapa telah begitu banyaknya kegiatan inovatif dalm upaya pengembangan kualitas kewarganegaraan yang demokratis sesuai dengan konteks masing-masing negara dan komunitas dalam negara itu.
Seperti kita ketahui bahwa dalam lingkungan masyarakat kita banyak dijumpai situs kewarganegaraan berupa kelompok masyarakat yang terorganisasi secara baik, artinya ada landasan hukum mereka berada serta ada aktifitas yang dijalankan sebagai bagian dari tujuan organisasi, seperti kelompok Majelis taklim, karang taruna, kelompok PKK, kelompok Arisan di tingkat RT/RW, kelompok pedagang, kelompok Tukang Ojeg, organisasi keterampilan seperti sanggar seni, organisasi bela diri, organisasi olah raga dan banyak lagi. Atau tempat-tempat berkumpulna warga secara rutin, seperti pos kamling, yang hampir setiap malam ada yang berkumpul dalam rangka tugas pengamanan kampung, pangkalan ojeg dimana banyak tukang ojeg yang sedang menjalankan tugas pekerjaannya, warung-warung dekat sekolahan yang setiap hari ramai dijadikan tempat nongkrongnya anak-anak sekolahan.

Sayangnya kelompok dan tempat berkumpulnya warga Negara tersebut tidak disentuh oleh pendidikan kewarganegaraan, padahal organisasi tersebut sesungguhnya sangat efektif untuk menjadi salah satu media untuk menyampaikan pendidikan kewarganegaraan dalam rangka membangun masyarakat yang demokratis dengan cara yang inovatif dan kreatif. 
3) Tidak adanya atau masih lemahnya komunikasi dan komitmen antar situs kewarganegaraan untuk membangun pendidikan kewarganegaraan.

Jika sekolah sebagai pihak yang bergerak dari jalur pendidikan formal dijadikan sebagai sentral pendidikan kewarganegaraan (center of civic education), maka saat ini PKn masih bergerak di persekolahan, sedangkan dilingkungan masyarakat dan keluarga asumsi penulis masih belum optimal, kalaupun ada, maka masih adanya ketidak sinkronan konten di dalamnya. Tidak sedikit siswa diberikan pendidikan nilai/watak di sekolah, tetapi ketika dating ke rumah dan lingkungan masyarakat semua nilai tadi gugur dengan sendirinya karena di rumah dan di lingkungan masyarakat tidak mendukung untuk terbentuknya nilai tadi menjadi suatu karakter. Sebagai contoh ketika disekolah dilarang dengan keras merokok, tetapi ketika dilingkungan masyarakat dan rumah mengabaikannya, bahkan keluarga dan tetanggannya merokok maka hal tersebut memgugurkan nilai yang diajarkan di sekolah, hal ini menjadi sorotan penulis, karena pada sisi ini situs kewarganegaraan tidak menjalankan tugasnya sebagai social control bahkan modeling, hal inilah yang mengakibatkan pemberian peluang kepada young generation yang secara psikologis sedang mencari jati diri untuk mencoba hal yang baru bahkan yang dianggap melanggar nilai/norma sekalipun karena tidak berfungsinya sosial kontrol dan teladan tadi dalam lingkungan masyarakat. Di satu sisi, ketika masalah sosial terjadi, pihak masyarakat/keluarga justru lebih menyalahkan pihak sekolah.

Hal ini adalah ironi, tentunya permasalahan dasar yang penulis temukan adalah selain ketidakfahaman pihak masyarakat bahwa mereka juga memiliki tanggungjawab moral dalam melakukan pendidikan kewarganegaraan juga kurangnya atau lemahnya komunikasi dan komitmen antar situs kewarganegaraan dalam hal ini sekolah sebagai pusat PKn dengan kelompok-kelompok masyarakat yang ada di lingkungannya.

Komunikasi, bahwa pihak sekolah dengan kurikulum yang diterapkan memiliki tanggung jawab melakukan pendidikan kewarganegaraan dengan karakter yang sudah ditetapkan, sehingga pihak masyarakat melalui situs-situs kewarganegaraan bahkan pihak orang tua mengetahui bersama.

Komitmen, muncukan komitmen bersama antar situs kewarganegaraan dimana sekolah sebagai center of civic education-nya bahwa mereka bersamasama untuk menjalankan pendidikan kewarganegaraan sesuai dengan fungsi dan perannya, serta menjadi modeling sekaligus social control bagi 
pengembangan warganegara muda yang demokratis demi terwujudnya civil society.

c. Beberapa Alternatif penyelenggaraan

Pendidikan Kewarganegaraan untuk Civic Community

Persoalan dasar pendidikan kewarganegaraan bagi masyarakat itu adalah kelembagaan dan konten dari PKn. Ada beberapa alternative solusi penyelenggaraan Pendidikan Kewarganegaraan untuk Civic Community dalam membangun civil society, sebagai berikut:

a. Pendekatan Kelembagaan:

1) Dibentuk lembaga khusus yang independen yang bertanggung jawab terhadap pelaksanaan Pendidikan Kewarganegaraan bagi masyarakat umum, seperti BP7 lalu. Dengan konsep, tujuan, sasaran, strategi yang jelas, kreatif dan inovatif, dalam rangka membentuk masyarakat Indonesia yang demokratis.

2) Jika no 1 tidak bisa, maka lembaga tersebut dapat menjadi bagian salah salah satu departemen tertentu, misalnya, masuk menjadi Kementrian Sosial atau kementerian Dalam Negeri, Kementerian Riset dan Pendidikan Tinggi.

3) Dijadikan program Nasional bagi seluruh Perguruan Tinggi di Indonesia, sebagai salah satu bentuk
Wajib Pengabdian Kepada

Masyarakat.

Tentunya kelembagaan ini, harus bergerak kepada masyarakat akar rumput yaitu situs-situs kewarganegaraan yang mendukung kehidupan sekolah.

Kelembagaan ini melakukan upaya pendidikan kewarganegaraan, dengan memiliki tiga tujuan, yaitu: pertama, memberikan/membangun pengetahuan, keterampilan dan sikap pihak masyarakat untuk menjadi civic society. Kedua, memberikan tanggung jawab kepada mereka sebagai modeling dan social control bagi anak-anak siswa sekolah (young generation) dalam kehidupan di masyarakat. Ketiga, menjadi fasilitator antar situs kewarganegaraan dimana sekolah menjadi center of civic education untuk membangun komunikasi dan komitmen dalam membangun civil society. Selain itu juga, kelembagaan ini harus didukung oleh sumber daya manusia yang profesional, yang menjadikannya pekerjaan tetap atau utama.

b. Pendekatan Konten

Tidak terlalu berbeda dengan Pendidikan Kewarganegaraan di persekolahan, yaitu memuat civic knowledge, civic skill, dan civic value/disposition, yang dimensi ini didasari dan mendasari pengembangan 


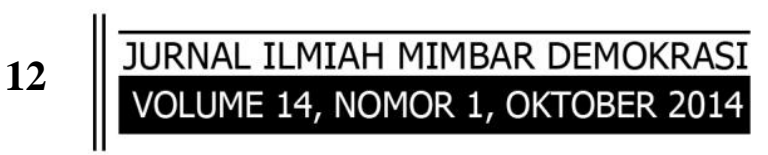

nilai-nilai Pancasila sebagai falsafat bangsa serta pandangan hidup bangsa Indonesia. Namun hal inilah yang perlu disosialissikan kepada situs kewarganegaraan yang ada.

$$
\text { Justru untuk Pendidikan }
$$

Kewarganegaraan pada masyarakat melalui situs-situs kewarganegaraan akan lebih kreatif dan inovatif dalam strategi/model/metode pembelajarannya. Sehingga kegiatan pembelajaran dapat dilakukan sesuai dengan kondisi dan tujuan dari organisasi/kelompok masyarakat itu sendiri.

\section{Kesimpulan dan Saran}

A. Kesimpulan

Dari hasil pembahasan di atas, maka penulis dapat membuat kesimpulan akan artikel ini sebagai berikut: Dalam upaya membangun masyarakat Demokratis berdasarkan Pancasila, pendidikan kewarganegaraan untuk masyarakat civil mendapatkan beberapa dua tantangan besar dalam pelaksanaannya, yaitu pertama kelembagaan, dimana saat ini tidak ada lembaga khusus yang dianggap bertanggung jawab untuk pengembangan pendidikan kewarganegaraan pada masyarakat, lemahnya komunikasi dan komitmen antar situs kewarganegaraan dalam upaya pendidikan kewarganegaraan. Kedua, konten dimana adanya situs kewarganegaraan pada masyarakat akar rumput, namun tidak secara sadar memiliki tanggung jawab untuk melaksanakan juga pendidikan kewarganegaraan, sehingga gerak langkah situs kewarganegaraan tersebut dalam hal konten pendidikan kewarganegaraan tidak optimal.

Untuk itu ada beberapa alternative untuk menyelesaikan masalah di atas, yaitu secara kelembagaan : 1) Dibentuk lembaga khusus yang independen yang bertanggung jawab terhadap pelaksanaan Pendidikan Kewarganegaraan bagi masyarakat umum, seperti BP7 lalu. Dengan konsep, tujuan, sasaran, strategi yang jelas, kreatif dan inovatif, dalam rangka membentuk masyarakat Indonesia yang demokratis. 2) jika no 1 tidak bisa, maka lembaga tersebut dapat menjadi bagian salah salah satu departemen tertentu, misalnya, masuk menjadi Kementrian Social atau kementrian Dalam Negeri, Kementrian Research dan Pendidikan Tinggi.3) Dijadikan program Nasional bagi seluruh Perguruan Tinggi di Indonesia, sebagai salah satu bentuk Wajib Pengabdian Kepada Masyarakat

Kelembagaan ini melakukan upaya pendidikan kewarganegaraan, dengan memiliki tiga tujuan, yaitu: pertama, memberikan/membangun pengetahuan, keterapilan dan sikap pihak masyarakat untuk menjadi civic society. Kedua, memberikan tanggung jawab kepada mereka sebagai modelling dan social 
control bagi anak-anak siswa sekolah (young generation) dalam kehidupan di masyarakat. Ketiga, menjadi fasilitator antar situs kewarganegaraan dimana sekolah menjadi center of civic education untuk membangun komunikasi dan komitmen dalam membangun civil society.

B. Saran

Dari kesimpulan-kesimpulan di atas. Maka penulis memberikan saran sebagai berikut:

1. Kepada Pihak Perguruan Tinggi

Lulusan Program Studi

Pendidikan Kewarganegaran harus memiliki kompetensi pengembangan pendidikan kewarganegaraan bagi masyarakat (civic community), sehingga perlu diadakannya mata kuliah yang berhubungan dengan itu.

2. Kepada Pihak Pemerintah

Pentingnya pendidikan kewarganegaraan bagi masyarakat, mengharuskan pihak pemerintah untuk segera membuat kelembagaan yang bertanggung jawab untuk pengembangan kewarganegaraan bagi masyarakat.

3. Kepada Pihak Masyarakat

Bagi situs-situs kewarganegaraan diharapkan secara aktif dapat ikut terlibat dalam program pendidikan kewarganegaraan ini dan mulai melakukan perannya sebagai social control dan modelling bagi siswa di sekolah.

4. Kepada Pihak Sekolah

Sekolah harus menjadikan pihak situs kewarganegaraan di luar sekolah menjadi partner dalam pendidikan kewarganegaraan bagi siswa dengan melakukan koordinasi, komunikasi dan komitmen agar situs kewarganegaraan yang ada di lingkungan sekolah dapat menjadi social control dan modelling bagi siswa di sekolah.

\section{DAFTAR PUSTAKA}

Campbell, David. E, Levinson, Meira \& Hess, Frederick M (2012), Making Civics Count, Citizenship for a New Generation, Cambridge, Massachusetts, Harvard Education Press.

Cogan, J. John \& Derricott, Ray (1998), Citizenship for the $21^{\text {st }}$ Century, An Introductional Prespective on Education (editor), London; Kogan Page.

Kardiman, Yuyus (2008), Membangun Kembali Karakter Bangsa Melalui Situs Kewargangeraan, Bandung; Sekolah Pasca Sarjana Universitas Pendidikan Indonesia.

Undang-Undang Nomor 20 Tahun 2003, tentang Sistem Pendidikan Nasional Indonesia.

Sapriya. (2007). Perspektif Pemikiran Pendidikan Kewarganegaraan dalam Pemabangunan Karakter 
$14 \quad \begin{aligned} & \text { JURNAL ILMIAH MIMBAR DEMOKRASI } \\ & \text { VOLUME 14, NOMOR 1, OKTOBER } 2014\end{aligned}$

Menurut Para Ahli. (Disertasi), Bandung, Sekolah Pasca Sarjana Universitas Pendidikan Indonesia.

Winataputra, U.S., (2001). Jatidiri Pendidikan Kewarganegaraan Sebagai Wahana Sistematik Pendidikan Demokrasi, Studi Kajian Konseptual dalam Konteks Pendidikan IPS (Disertasi), Bandung: Program Pascasarjana Universitas Pendidikan Indonesia.

Winataputra, U.S., dan Budiansyah, Dasim (2007), Civic Education, Konteks, Landasan, Bahan Ajar dan Kultur Kelas, Bandung, Sekolah Pasca Sarjana Universitan Pendidikan Indonesia. 